\title{
Systematic Study of Micro Air-Jet Engine
}

\author{
P Vikas ${ }^{1}$ N Aravind ${ }^{2}$ P Shashidhar ${ }^{3}$ Benjamin $^{4}$ K Dinesh ${ }^{5}$ Jv Muruga lal Jeyan ${ }^{6}$ \\ 1, 2,3,4,5 UG Scholar, Department of Aerospace Engineering, Lovely Professional University, \\ Punjab, India-144411
}

6, Professor in Department in Aerospace Engineering, Lovely Professional University, Punjab, India144411

\begin{abstract}
In this paper we are going to review about small scale Micro-Jet engine and this study is based on various research articles and available data in public domain (Open Access) on Internet. We have performed a detail study on some well-known research papers in this field and has depicted the importance of Micro and Mini turbine engines in detail. We have mentioned the engine specifications and some of the basic characteristics of Micro-Jet engines and had performed a comparison-based study with various Micro sized turbine/Jet engines available in market today. Also, a specification-based comparison is made between those Micro Jet engines with real sized Jet Engine. We have discussed about various advantages and uses of such small-scale Jet engines in various research institutes in today's world. Such Micro sized Jet engines are used in Institutes and Universities for performing experiments to teach students in a more practical manner, rather than theoretical way. The use of these Jet engines in the defence industry is also discussed in this paper in detail.
\end{abstract}

Keywords: Jet Engine, Micro-Turbine engine, Specific Fuel Consumption, Propulsion, Aircrafts.

\section{Introduction}

Micro turbine Engines (MTE's) are small scale model of the real jet engines which are used in aircrafts to power them. Some of the Micro-Turbine Engines are exact copy of the real size jet engine, but on a scaled down manner. There are various sizes of Micro-Turbine Engines available in market for varied purposes depending on factors such as Thrust Produced, Fuel Used, Specific Fuel Consumption (SFC), Thrust Specific Fuel Consumption (TSFC), and Thrust to Weight ratio (T/W) and Structural requirement of the user. The scaled down design of the Micro-Turbine Engine was first proposed by a group of enthusiasts of aviation model making. There was a need of finding of real engines, but in micro scale for propulsion of turbojet or turboprop aircraft model. The developments made in the field has been in the interest of defence forces for various surveillance and unmanned missions. This paved a way for development of Unmanned Aerial Vehicles (UAV) and drones, which are now prominently serving in armed forces worldwide.

Micro-Turbine engines can also be useful for various scientific experimental process in aerospace sector, just by using this MicroTurbine Engine in scaled down aircraft model for testing purposes of various new aircraft design and analysing various flight parameters and defining new flight characteristics for future of aviation industry. Recently NASA and many other private aerospace giants such as Lockheed martin has tested some technology demonstrators UAV's with these Micro Jet Engines. some of the UAV prototypes are X-56A, etcAs these MicroTurbine Engines got into fame, many aerospace companies started designing and manufacturing of these MTE's as per the requirements and demand in the market. At present the biggest consumer of such MTE's are the armed forces around the globe, which are using such aerial technologies in their defence forces for modernising their inventory and to keep an edge over their enemy counterpart.

\section{Working Principle of Jet Engine}

Jet Engine basically works on the principle of conservation of momentum, where the frontal section of the engine sucks the fastmoving jets that generates thrust by increasing the kinetic energy of the jet and then pushing the combusted air back through the nozzle generating an amount of thrust. Principle of conservation of Momentum says that at very high speed/velocity, large momentum is created by the backward gases. This leads to an equal and opposite momentum to the jet engine by which the jet engine moves forward with a great speed. 
If we see thermodynamically, a Jet engine works on Brayton Cycle, a thermodynamic cycle that underlies all Gas Turbine Engines. A Brayton cycle properly explains the thermodynamic processes happening in a Jet Engine and describes the management of heat and energy by the engine to produce the work done, in this case the Thrust Produced is shown in the graph.
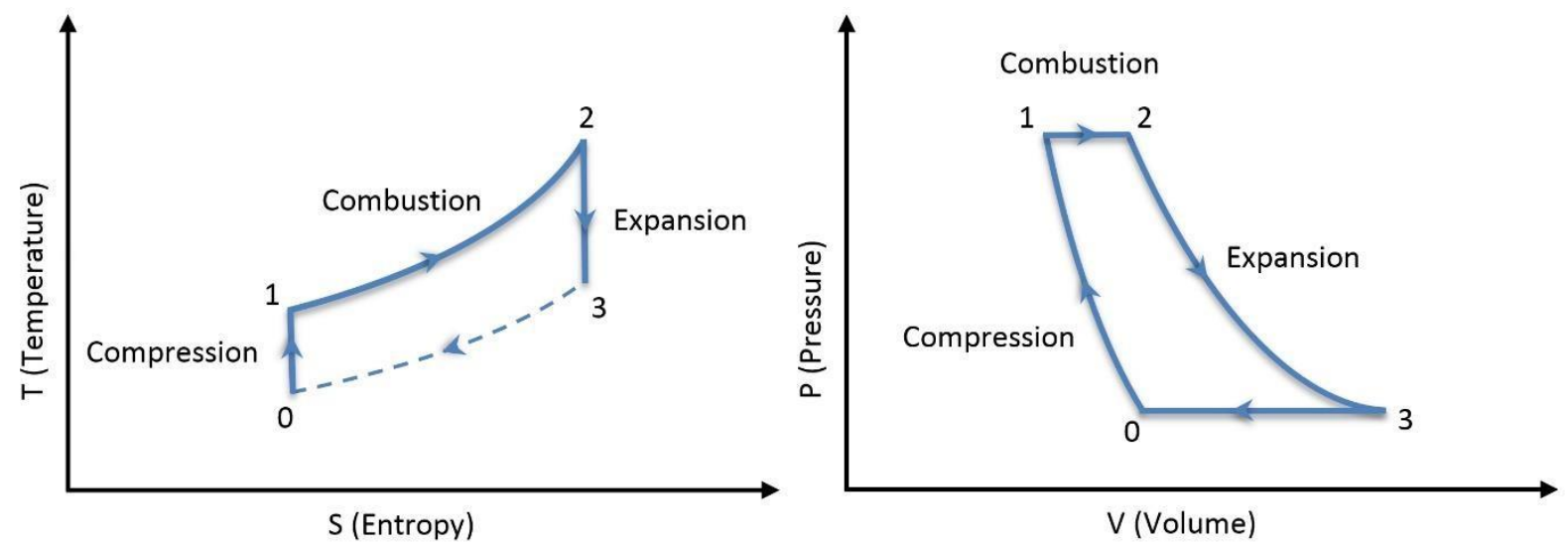

Figure 1: T-S and P-V diagram of Brayton Cycle (web link)

A brief explanation of Temperature vs Entropy and Pressure vs Volume diagrams is given below with Jet engine schematic of various processes occurring in the Brayton Cycle.

For analysing the thermodynamic processes involved in the operation of a Jet engine, Let's divide the engine into important sections, based on the thermodynamic processes that occurs within the engine, such as Compression, combustion, and expansion. The diagram given below is divided into five sections, they are Inlet, Compressor, Combustor, Turbine and Nozzle.

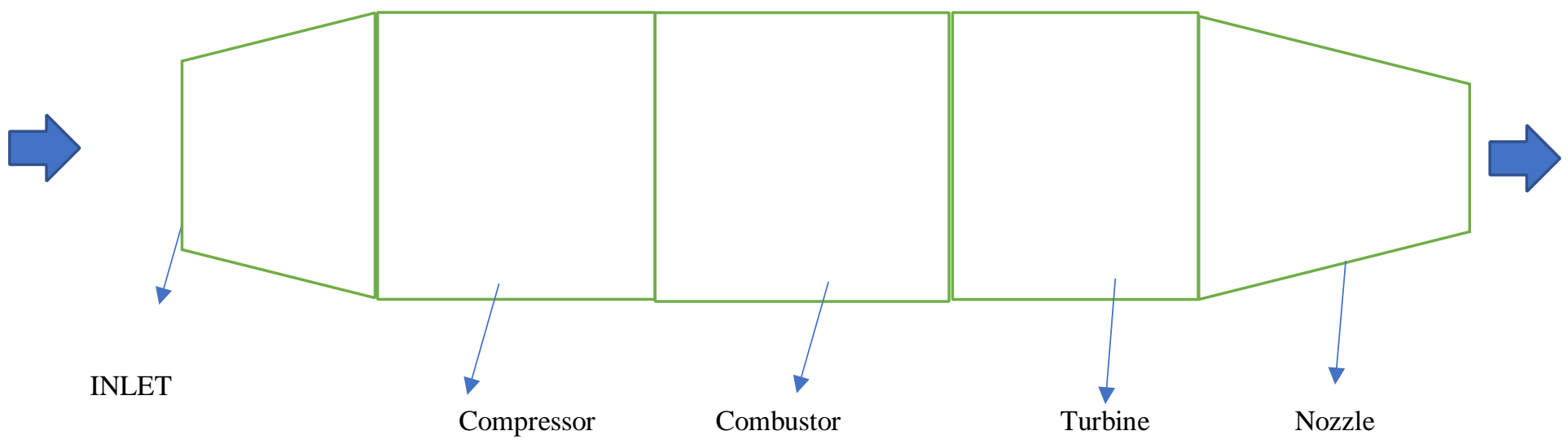

Figure 2: Thermodynamic sections of a Jet Engine

In the given engine schematic, the Brayton cycle starts at 0 , at the Inlet section. From 0 to 1 , the air enters the engine through the divergent Inlet and then gets compressed at constant Entropy (Isentropic Process) into the Compressor, where pressure increases and volume decreases. From 1 to 2, the compressed gas enters the Combustion Chamber (CC), and fuel is mixed with the compressed air resulting in combustion at constant pressure (Isobaric Process). From 2 to 3, the combusted fuel-air mixture then enters the turbine section where expansion takes place adiabatically and isentropically, also the flow velocity increases. At the end, the air flows out of the engine through nozzle producing thrust. All the processes occur in an Ideal condition only. As real jet engines do not operate ideally, so in real various other factors comes into consideration 


\section{Literature Review}

Here, we will discuss about various research articles related to Micro-Turbine Engine and will review it briefly.

[1]

This paper depicts the way and reason for using Mini-Jet Engines in Universities for teaching propulsion to students, due to various advantages such as low cost, simplicity in construction, easy operation and behaviour as a full-size jet engine. The engine chosen here is FD3, which is based on a miniature jet engine design by a German Engineer, KURT SCHRECKLING.

The performance characteristics of this engine is given below,

$\begin{array}{llc}\text { Maximum Diameter } & : & 110 \mathrm{~mm} \\ \text { Length } & : & 265 \mathrm{~mm} \\ \text { Diameter of Compressor Wheel } & : & 66 \mathrm{~mm} \\ \text { Diameter of Turbine Wheel } & : & 63.5 \mathrm{~mm} \\ \text { Engine Weight } & : & 870 \mathrm{~g} \\ \text { Thrust at 75000 rpm } & : & 24 \mathrm{~N} \\ \text { Pressure Ratio } & : & 1.4 \\ \text { Air Mass Flow } & : & 0.115 \mathrm{~kg} / \mathrm{s} \\ \text { Fuel Consumption } & : & 160 \mathrm{ml} / \mathrm{min} \\ \text { Oil Consumption } & : & 2 \mathrm{ml} / \mathrm{min} \\ \text { Exhaust Efflux Speed } & : & 209 \mathrm{~m} / \mathrm{s} \\ \text { Exhaust Gas Temperature } & : & 630^{\circ} \mathrm{C} \\ \text { Self-Sustaining Speed } & : & 8000 \mathrm{rpm} \\ \text { Idle Speed } & : & 20000 \mathrm{rpm}\end{array}$

Maximum Rotational Speed : $\quad 80000 \mathrm{rpm}$ Thrust Range : $\quad 2$ to $24 \mathrm{~N}$

A comparison was also made between miniature jet engines and a full-size jet engine. Where three miniature jet engines were considered for comparison i.e., FD3, MT and JPX with a full-size jet engine i.e., CF6-80C. The comparison was made based on some of the basic characteristics mentioned below in the table,

Table 1: Comparison between Mini and Full-size Jet Engine

\begin{tabular}{|l|c|c|c|c|}
\hline Characteristics & FD3 & MT & JPX & CF6-80C \\
\hline Project & Schreckling & Kamps & Turborec & $\begin{array}{c}\text { GE, MTU, } \\
\text { SNECMA }\end{array}$ \\
\hline Thrust $(\mathrm{N})$ & 30 & 33 & 45 & 262500 \\
\hline Mass $(\mathrm{kg})$ & 0.75 & 1.14 & 1.7 & 4066 \\
\hline Pressure Ratio & 1.5 & 2 & 2.15 & 32 \\
\hline Turbine Intake temperature $\left({ }^{\circ} \mathrm{C}\right)$ & 700 & 650 & 740 & 1280 \\
\hline Specific Thrust $(\mathrm{N} / \mathrm{kg})$ & 40 & 29 & 26 & 65 \\
\hline Consumption $(\mathrm{kg} / \mathrm{min})$ & 0.16 & 0.14 & 0.12 & 158 \\
\hline Specific Consumption $(\mathrm{kg} / \mathrm{N} / \mathrm{h})$ & 0.32 & 0.25 & 0.16 & 0.036 \\
\hline
\end{tabular}

This Study shows that the use of Mini Jet Engines in Universities for education purposes provides students with practical working knowledge of a real size Jet Engine and helps students to understand the theoretical concepts better with experimental analysis. 
This paper is based on the parametric performance analysis of a miniature sized Jet Engine which was studied at Myanmar Aerospace Engineering University. Some of the main operating factors taken into consideration was Compressor Pressure Ratio $\left(\pi_{\mathrm{c}}\right)$ and Turbine Inlet temperature $\left(\mathrm{T}_{\mathrm{t}}\right)$, which affects the Specific Thrust $\left(\mathrm{F}_{\mathrm{s}}\right)$ and Specific Fuel Consumption $(\mathrm{S})$, on which the total engine performance is based. [2]

Various use of Jet Engines has been studied in this paper such as electric power generation, heat generation, power source in desalination plant for absorbing heat, aircraft applications, etc. For generating electricity, some of the main features of a mini jet engine is that the high-speed generator is directly coupled to the turbine rotor, and they use power electronics instead of a gearbox and a conventional generator to adapt the power produced to the grid power quality. The Brayton Working Cycle is discussed, in which the engine working engine fluid exhaust in the atmosphere after expansion in turbine and the exhaust is propelled in nozzle at ideal conditions. In real there are various other parameters to be considered in a turbojet engine, such as component losses, mass flow rate of fuel through components and the variation of specific heats.

In this paper, the analysis is based on the assumptions of one-dimensional flow at the entrance and exit of each component. A parametric study was performed with a main objective of relating the engine performance parameters (primarily Thrust $(\mathrm{F})$ and Thrust Specific Fuel Consumption (TSFC)), to design choices (Compressor Pressure Ratio, Fan Pressure Ratio, By-pass Ratio, etc.), to design limitations (Burner Exit Temperature, Compressor exit pressure, etc.), and to flight environment (Mach Number, Ambient Temperature, etc.). The parameters - Inlet Mach Number $\left(\mathrm{M}_{0}\right)$ and Compressor pressure ratio $\left(\pi_{\mathrm{c}}\right)$ were provided with various input data such as Inlet temperature $\left(\mathrm{T}_{0}\right)$, Diffuser total pressure ratio $\left(\pi_{\mathrm{dmax}}\right)$, Burner total pressure ratio $\left(\pi_{\mathrm{n}}\right)$, Compressor polytropic efficiency $\left(\mathrm{e}_{\mathrm{c}}\right)$, Turbine polytropic efficiency $\left(\mathrm{e}_{\mathrm{t}}\right)$, Burner Isentropic efficiency $\left(\mathrm{n}_{\mathrm{b}}\right)$, combustor pressure loss $\left(\mathrm{n}_{\mathrm{m}}\right)$, Static pressure ratio of inlet to nozzle $\left(\mathrm{P}_{0} / \mathrm{P}_{9}\right)$, and fuel low heating value $\left(\mathrm{h}_{\mathrm{PR}}\right)$, for analysing the data against various performance parameters of a Jet engine.

The result of these inputs obtained various graphical performance statistics of a Jet engine depicting the graphs of Inlet Mach number with variation of Specific thrust, Specific fuel consumption, Propulsive efficiency, and Thermal efficiency. Similarly, graphs of Compressor pressure ratio are also obtained with variation of Specific thrust, Specific fuel consumption, propulsive efficiency, and thermal efficiency.

According to types related to its configuration vary with efficiency, non-Recuperated has efficiency nearly $50 \%$, Recuperated has efficiency between $20-30 \%$, with heat recovery system, we can achieve efficiency up to $85 \%$. So, if we compare according to efficiency, the engine equipped with heat recovery system has highest efficiency as compared to recuperated and nonrecuperated engines.[3]

The technology of Micro-turbines came into existence during 1970's. The interest in this technology was started to spread in the mid 1980's and till 1990's it started booming around market. Its main advantage is low maintenance cost, high reliability, compact size, close resemblance in performance with real size Jet engine. The very first micro-turbine was designed to be used in missile launching vehicle, also in unmanned aircrafts.

In the year 1978, Allison has started development and construction of generating grids for military application because for testing purpose of big aircrafts result in high consumption of fuel, noise pollution and frequency stability, considering all this conditions they had small gas turbines which were used to reduce high consumption fuel and other factors. After this typically aviation sector rated at $50 \mathrm{~kW}$ and equipped the engine with heat recovery by efficiency got high end use in military applications for Patriot Missile launching

Different types of micro jet engines with specificationsMicro turbo UAV's Engines for drone propulsion J Dutczak from Creaw University. micro turbines are playing an important role in terms of support, security, and knowledge.In addition, Aero Enthusiasts are modelling and designing many sorts of Micro Jet Engines, and their efforts to develop for various uses have turned into full-time aviation constructions. Currently, military unmanned aerial vehicles (UAVs) are in high demand, such as the Lockheed Martin-designed X-56A, on which NASA is working diligently. [11] 
Some Examples and technical specifications are provided

\begin{tabular}{|c|c|c|c|c|c|c|}
\hline & $\begin{array}{l}\text { Kolibri } \\
\text { T15 }\end{array}$ & Hawk 240R & Hawk 100R & $\begin{array}{l}\text { Bee II } \\
\text { Kero } \\
\text { Start }\end{array}$ & $\begin{array}{l}\text { Bee II } \\
\text { Turbo } \\
\text { Prop }\end{array}$ & $\begin{array}{l}\text { KS } \\
\text { Taurus } 10\end{array}$ \\
\hline $\begin{array}{l}\text { Idle thrust }[\mathrm{N}] / \\
\text { RPM }\end{array}$ & $\begin{array}{l}\text { ca. 2/ } \\
95000\end{array}$ & $8 / 39000$ & $6 / 60000$ & $\begin{array}{l}3.6 / \\
55000\end{array}$ & - & - \\
\hline $\begin{array}{l}\text { Maximum Thrust } \\
{[\mathrm{N}] /} \\
\text { RPM }\end{array}$ & $15 / 243000$ & $240 / 132000$ & $110 / 175000$ & $\begin{array}{l}70 / \\
18500 \\
0\end{array}$ & - & - \\
\hline $\begin{array}{l}\text { Maximum Power } \\
{[\mathrm{Kw}] / \mathrm{RPM}}\end{array}$ & - & - & - & - & $\begin{array}{l}9 / \\
180000\end{array}$ & $10 / 123000$ \\
\hline Pressure ratio & 2.2 & $1.2-4.6$ & $1.2-3.6$ & - & - & - \\
\hline RPM & $\begin{array}{l}95000- \\
243000\end{array}$ & $\begin{array}{l}39000- \\
132000\end{array}$ & $\begin{array}{l}60000- \\
175000\end{array}$ & $\begin{array}{l}55000 \\
- \\
18500 \\
0 \\
\end{array}$ & $\begin{array}{l}55000- \\
180000\end{array}$ & $\begin{array}{l}33000- \\
123000\end{array}$ \\
\hline $\begin{array}{l}\text { Prop-shaft RPM } \\
\text { range }\end{array}$ & - & - & - & - & $\begin{array}{l}6000- \\
8000\end{array}$ & $9000 \max$ \\
\hline $\begin{array}{l}\text { Exhaust Gas } \\
\text { Temperature }\left[{ }^{\circ} \mathrm{C}\right]\end{array}$ & $\max 680$ & $\begin{array}{l}400-760 \\
(800)\end{array}$ & $390-760$ & $\begin{array}{l}500- \\
700\end{array}$ & $500-700$ & $550-750$ \\
\hline $\begin{array}{l}\text { Fuel consumption } \\
{[\mathrm{g} / \mathrm{min}]}\end{array}$ & ca. $50(\max )$ & $65-515$ & $30-260$ & $\begin{array}{l}180 \\
(\max )\end{array}$ & $\begin{array}{l}135 \\
\text { (average) }\end{array}$ & $135-230$ \\
\hline Fuel type & $\begin{array}{l}\text { Kerosene } \\
\text { JetA1 } \\
\text { Petroleum }\end{array}$ & $\begin{array}{l}\text { Jet A1 } \\
\text { Diesel } \\
\text { (EN590) }\end{array}$ & $\begin{array}{l}\text { Kerosene } \\
\text { Premium } \\
\text { paraffin } \\
\text { Kerosene } \\
\text { Jet-A1 } \\
\text { Diesel } \\
\text { (EN590) }\end{array}$ & $\begin{array}{l}\text { Kerose } \\
\text { ne Jet } \\
\text { A1 }\end{array}$ & $\begin{array}{l}\text { Diesel } \\
\text { (EN590) } \\
\text { Kerosene } \\
\text { Jet A1 }\end{array}$ & $\begin{array}{l}\text { Diesel } \\
\text { (EN590) } \\
\text { Jet A1 }\end{array}$ \\
\hline $\begin{array}{l}\text { Spool time (idle to } \\
\max . \\
\text { thrust) [s] }\end{array}$ & ca. 2.5 & 4.5 & 4 & 3 & 4.2 & ca. 4 \\
\hline $\begin{array}{l}\text { Lubrication (oil- } \\
\text { fuel mixture }\end{array}$ & $\begin{array}{l}5[\%] \\
\text { Aeroshell } \\
500\end{array}$ & $\begin{array}{l}1.5[\%] \text { Two } \\
\text { stroke } \\
\text { outboard }\end{array}$ & $\begin{array}{l}1.5[\%] \text { Two } \\
\text { stroke outboard }\end{array}$ & $\begin{array}{l}2.0- \\
2.5 \\
{[\%]} \\
\text { Two } \\
\text { stroke } \\
\text { synth. } \\
2.5- \\
5.0 \\
{[\%]} \\
\text { Turbin } \\
\text { e } \\
\text { synthet } \\
\text { ic }\end{array}$ & $\begin{array}{l}2.0-2.5 \\
{[\%]} \\
\text { Two } \\
\text { stroke } \\
\text { synth.2.5 } \\
-5.0[\%] \\
\text { Turbine } \\
\text { synthetic }\end{array}$ & $\begin{array}{l}5[\%] \\
\text { Turbine } \\
\text { synthetic }\end{array}$ \\
\hline Engine control & FADEC & FADEC & FADEC & $\begin{array}{l}\text { FADE } \\
\mathrm{C}\end{array}$ & FADEC & FADEC \\
\hline Start system & $\begin{array}{l}\text { Propanebutane } \\
\text { External } \\
\text { Air }\end{array}$ & $\begin{array}{l}\text { Propanebutane } \\
\text { Full auto start }\end{array}$ & $\begin{array}{l}\text { Propanebutane } \\
\text { Full auto start }\end{array}$ & $\begin{array}{l}\text { Kerose } \\
\text { ne Full } \\
\text { auto } \\
\text { start }\end{array}$ & $\begin{array}{l}\text { Kerosene } \\
\text { Full auto } \\
\text { start }\end{array}$ & $\begin{array}{l}\text { Kerosene } \\
\text { Full auto } \\
\text { start }\end{array}$ \\
\hline Compressor & - & Radial & Radial & Radial & Radial & - \\
\hline
\end{tabular}




\begin{tabular}{|l|l|l|l|l|l|l|}
\hline $\begin{array}{l}\text { Combustion } \\
\text { chamber type }\end{array}$ & - & Reverse flow & Reverse flow & $\begin{array}{l}\text { Annul } \\
\text { ar }\end{array}$ & Annular & - \\
\hline Turbine type & - & radial & radial & axial & axial & - \\
\hline $\begin{array}{l}\text { Number of turbines } \\
1\end{array}$ & 1 & 1 & 1 & 1 & 2 & 2 \\
\hline
\end{tabular}

Table represent different specification of micro jet turbine [4], [5], [6], [7], [8], [9]

\section{Future Scope of Micro-Jet Engines}

As the demand for such small-scale Micro Jet engines is on a rise in the market due to rising demand in various research Institutes and Universities for experimental purposes, we can predict the future of these Micro-Jet Engines to be on a positive side. These small sized jet engines require less maintenance and gives performance output like about the real size Jet engine. Some of the basic advantages of Micro Jet engines over the real sized Jet engines, such as Low maintenance Cost, High reliability, Low Fuel Consumption, Easy Manufacturing, Compact Size, etc. makes this an ideal choice for Experimental usage in Research work and provides close resemblance with real sized Jet engine with almost $90 \%$ accuracy and comes out to be an efficient choice for the user. There are many such small jet engines available in market now-a-days, so it's easily accessible by normal population without any restrictions and doesn't violate any fundamental security aspect of any government policy.

Now-a-days, many small-scale Industries are getting involved in the manufacturing process of these small-scale Jet Engines with minimum Investment and are providing affordable services to their users very efficiently and effectively. These engines are also used in Defence industry on a large scale in today's time, enabling new generation of unmanned and robotic involved warfare. Such Micro -Jet engines were firstly modelled to be used in small RC aircraft models and toys for various competitions of RC models around the globe. But, with time the situation changed and now the upgraded versions of such Micro Jet Engines are used in small military unmanned aircrafts to perform various roles in battlefield, such as surveillance, small scale Bombing, Fire hydrant, Missile testing, etc. There are various nations around the globe working towards achieving this technology and some of the developed nations are working towards further iterations of these small-scale engines, making it more efficient and affordable for normal people. Some of the researchers are still working on this technology to make proper use of these small engines in other fields also, such as electricity production, temperature management- heating and cooling system, etc. All these advantages shows that there can be multiple other uses of Micro-Jet Engines in future and further time to come, and these will serve in the benefit of humanity and to make human life more comfortable and energy sufficient.

\section{Conclusion}

Jet Engine technology comes under the list of some of the most critical technologies, only few nations around the globe posses this technology till date. A lot of maturation time is required to acquire this technology fully and still there is scope for improvement after that as well. Many developed nations have spent billions of dollars on the Research and Development of this technology and are still not perfect in this. For countries which are currently under developmental phase of their Jet engine, this concept of Micro Jet Engine can be a most affordable option to perform various experimental research and analysis for their Jet engine. As these smaller jet engines gives almost similar performance as the real size jet engine. This concept of miniaturizing the Jet engine is coming out to be a revolutionary idea in the field of propulsion and is very beneficial for the progress of aviation and many other sectors including energy production.

\section{REFRENCES}

[1] Jose Eduardo Mautone Barros (Brazil) Miniature Jet Engine applied to Propulsion Education,

[2] Kyaw Kyaw Shwe, Zar Zar Aye, Than Swe Parametric Performance Analysis of a Mini Jet Engine,

[3] Piyush Jha, Anuradha Tomar] Optimal Scheduling of Microgrid using AI techniques

[4] http://www.jetcentral.com.mx/products/turbo-prop-ks/ 
[5] http://www.hawkturbine.com/Technicalspec.htM- [6] http://www.hawkturbine.com/Technicalspecxxx.htm

[7] http://www.hawkturbine.com/Technicalspecxxx.htm

[8] http://www.jetcentral.com.mx/products/bee-ii-ks/

[9] http://www.pahlhelicopter.com/index_htm_files/Taurus\%20Daten_2012

[10] http://www.modellbau-peters.de/kolibri-turbine-t15-ohneautostart

[11] Dutczak Institute of Automobiles and Internal Combustion Engines, Cracow University of Technology, 